ALMEIDA, I.P.C.; SILVA, P.S.L.; NEGREIROS, M.Z.; BARBOSA, Z. Baby corn, green ear, and grain yield of corn cultivars. Horticultura Brasileira, Brasília, v.23, n.4, p.960-964, out-dez 2005.

\title{
Baby corn, green ear, and grain yield of corn cultivars
}

\author{
Itala Paula de C. Almeida ${ }^{1 ; 2}$; Paulo Sérgio L. e Silva ${ }^{1 ; 3}$; Maria Z. de Negreiros ${ }^{1}$; Zenaide Barbosa ${ }^{4}$

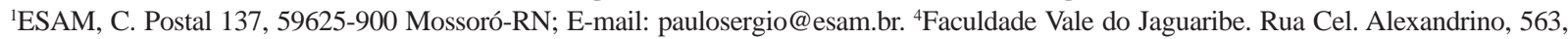 \\ Centro, 62800-000 Aracati-CE; E-mail: fvj@ secrel.com.br; ${ }^{3}$ bolsista do CNPq (autor correspondente); ${ }^{2}$ Estudante mestrado da ESAM.
}

\begin{abstract}
Most maize cultivars have been developed for grain production. Because superior cultivars may differ in their exploiting purposes, interest has been demonstrated for the evaluation of corn cultivars with regard to their baby corn, green ear, and grain yields production ability. In the present work ten corn cultivars (AG 405, AG 1051, AG 2060, AG 6690, AG 7575, AG 8080, DKB 333 B, DKB 435, DKB 350 and DKB 747) were evaluated in the yield of baby corn, green ears and dry grains. Two experiments were carried out in the same season, in neighboring areas and managed in a similar way, in Mossoró, Rio Grande do Norte State, Brazil, in a randomized blocks design with five replicates. Baby corn yield $\left(178,571\right.$ plants ha $\left.^{-1}\right)$ was evaluated in one of the experiments. The other experiment $\left(50,000\right.$ plants ha $\left.^{-1}\right)$ was set to evaluate green ear and dry grain yield. Cultivars DKB 350 and AG 8080 were the most productive in number and weight of marketable unhusked, and husked baby corn ears. Cultivars DKB 435 and AG 8080 were the most productive in number and weight of marketable, unhusked, and husked ears. There were no differences between cultivars for grain yield.
\end{abstract}

Keywords: Zea mays L., green corn.

\section{RESUMO}

Rendimentos de minimilho, de espigas verdes e de grãos de cultivares de milho

Desde que a maioria das cultivares de milho foi desenvolvida para produção de grãos, existe interesse em se avaliá-las quanto à produção de minimilho e espigas verder pois as cultivares superiores podem diferir, dependendo da finalidade de exploração da cultura. O objetivo do trabalho foi avaliar as produções de minimilho, espigas verdes e de grãos de dez cultivares (AG 405, AG 1051, AG 2060, AG 6690, AG 7575, AG 8080, DKB 333 B, DKB 435, DKB 350 e DKB 747) de milho. Dois experimentos, conduzidos na mesma época, em áreas vizinhas e manejados de forma semelhante, foram realizados em Mossoró-RN, no delineamento de blocos ao acaso com cinco repetições. Em um deles (178.571 plantas ha $\left.{ }^{-1}\right)$ avaliou-se a produção de minimilho. No outro (50.000 plantas ha $\left.{ }^{-1}\right)$, avaliaram-se as produções de espigas verdes e de grãos. As cultivares DKB 350 e AG 8080 mostraram-se as mais produtivas em número e peso de espigas de minimilho comercializáveis, empalhadas e despalhadas. As cultivares DKB 435 e AG 8080 mostraram-se as mais produtivas quanto aos números e pesos de espigas verdes comercializáveis, empalhadas e despalhadas. Não houve diferença entre cultivares quanto ao rendimento de grãos.

Palavras-chave: Zea mays L., milho verde.

(Recebido para publicação em 18 de fevereiro de 2005 e aceito em 5 de agosto de 2005)

$\mathrm{T}$ The cultivation of corn (Zea mays L.) for "green corn" and grain production is one of the most important activities of the Brazilian Northeastern agriculture. Corn ears harvested with a moisture content of the grains between 70 and $80 \%$ is called "green corn". In the first semester of the year, fruit producing companies without other cropping options successfully explore corn in the areas previously occupied with melon plants, in order to produce green ears, grains, and stubble (aboveground plant parts, without ears), under dryland conditions, and where irrigation is possible. Under these conditions, another option to explore corn would be the production of "baby corn".

"Baby corn" consists of the husked ear, harvested two or three days after silk emergence. "Baby corn" is a profitable crop that allows a diversification of production, aggregation of value, and increased income (PANDEY et al., 2002). As a product, it is only important in Thailand and a few other countries (PEREIRA FILHO et al., 1998). Because of globalization, other countries have become interested in this crop. Brazil has a promising market because the demand for baby corn is rising and production almost does not exist. There is also a perspective of exportation to other markets, especially those that already import a variety of Brazilian vegetable products. In addition to supplying the growing domestic demand, this product could be included in the export list of agricultural companies, taking advantage of the existing export chain used for fruits, ornamental plants, and other products. Therefore, the evaluation of baby corn production under the conditions of the Brazilian Northeast should be interesting.
There are three reasons to evaluate corn cultivars introduced into the Brazilian Northeast, with regard to their baby corn, green ear, and grain yields. These cultivars are frequently used by growers without being previously evaluated for the Northeastern conditions. Second, these cultivars differ in their green ear and grain yield, and not always the best cultivars for green corn yield are also the best for grain yield (SILVA; PATERNIANI, 1986; SILVA; SILVA, 1991; SILVA et al., 1997; SILVA et al.,1998). Last, specific cultivars for the production of baby corn still do not exist in Brazil, but research works involving cultivars developed for other purposes indicate differences between them (PEREIRA FILHO et al., 1998; CARVALHO, 2002). Apparently, the data upon which the present work was based are pioneer on this subject in the Brazilian Northeast. The objective 
of this work was to evaluate the ability of production of baby corn, green ear, and grain yields of ten corn cultivars.

\section{MATERIAL AND METHODS}

Corn cultivars produced by the Monsanto company, were evaluated in two experiments carried out under dryland conditions, irrigated by sprinkling as needed: DKB 333B and AG 7575 (single-cross hybrids); DKB 350, AG 8080 and AG 6690 (three-way cross hybrids); DKB 435, DKB 747, AG 2060, AG 405 and AG 1051 (doublecross hybrids). The experiment was sprinkler-irrigated with a $5.6 \mathrm{~mm}$ water depth and a one-day watering schedule. The water depth required was calculated considering an effective depth of the root system of $0.40 \mathrm{~m}$. Irrigation time was based on the water retained by the soil at a tension of $0.04 \mathrm{Mpa}$.

Experiment 1: Baby corn yield and other traits

The research was carried out at the Rafael Fernandes Experimental Farm, located $20 \mathrm{~km}$ away from Mossoró, Rio Grande do Norte State ( $5^{\circ} 11^{\prime} \mathrm{S}$ latitude, $37^{\circ} 20^{\prime} \mathrm{W}$ longitude, and $18 \mathrm{~m}$ altitude), from December 2002 to April 2003. The experimental soil was classified as a Podzólico Vermelho-Amarelo Eutrófico. Analysis of this soil presented the following results: $\mathrm{pH}=6.7, \mathrm{Ca}+\mathrm{Mg}=$ $4.00 \mathrm{cmol}_{\mathrm{c}} \mathrm{dm}^{-3}, \mathrm{~K}=0.27 \mathrm{cmol}_{\mathrm{c}} \mathrm{dm}^{-3}$, $\mathrm{Na}=0.09 \mathrm{cmol}_{\mathrm{c}} \mathrm{dm}^{-3}, \mathrm{Al}=0.04 \mathrm{cmol}_{\mathrm{c}}$ $\mathrm{dm}^{-3}$, and organic matter $=11.42 \mathrm{~g} \mathrm{~kg}^{-1}$.

The soil was tilled by means of two harrowings and received, at sowing, 30 $\mathrm{kg} \mathrm{ha}^{-1} \mathrm{~N}$ (urea), $60 \mathrm{~kg} \mathrm{ha}^{-1} \mathrm{P}_{2} \mathrm{O}_{5}$ (single superphosphate), and $30 \mathrm{~kg} \mathrm{ha}^{-1} \mathrm{~K}_{2} \mathrm{O}$ (potassium chloride). Half of the nitrogen, all phosphorus, and all potassium were applied as planting fertilization, in furrows located beside and below the seeding furrows. The rest of the nitrogen $\left(30 \mathrm{~kg} \mathrm{ha}^{-1}\right)$ was applied, as sidedressing, after weeding. Seeds were planted on $12 / 20 / 2002$ using two seeds per pit, at $0.80 \mathrm{~m} \times 0.07 \mathrm{~m}$ row spacing. Thinning was performed 22 days after seeding, leaving one plant per pit $\left(178,571\right.$ plants ha $\left.^{-1}\right)$. Pest control was done by means of three deltamethrin sprays $\left(250 \mathrm{ml} \mathrm{ha}^{-1}\right)$, performed $7 ; 14$ and 24 days after sowing; weed control was performed by hoeing 35 days after sowing.

A randomized blocks design with five replicates was used. Plots consisted of five plant rows with six meters in length. The usable area consisted of the three central rows eliminating six plants of each end.

The evaluated traits were total number and weight of ears; number and weight of marketable unhusked ears; number, weight, length, and diameter of husked ears to be sold fresh or preserved; fresh and dry mass of the above-ground part of the plant, tassels, and roots; leaf area, stalk diameter, plant height, and ear insertion height. The total number and weight of ears were estimated based on the total number of ears harvested from the usable area of the plot. Unhusked ears, free of damage caused by pests or diseases were considered marketable. Husked ears that presented good health, a color varying from pearly white to light yellow, cylindrical shape with a diameter ranging from 0.8 to $1.8 \mathrm{~cm}$ and length ranging from 4 to $12 \mathrm{~cm}$ were considered marketable. The number of ears to be sold as preserves was also determined (diameter between $1.0 \mathrm{~cm}$ and $1.5 \mathrm{~cm}$, and length ranging from 5 to $10 \mathrm{~cm}$ ). Marketable ear diameter and length were evaluated using a caliper rule. The fresh and dry matter weight of ears, the above-ground part, root system, and tassels were estimated based on 10 ears, five crushed plants, the crushed roots of two plants, and ten tassels, respectively. Leaf area was determined using one plant from each plot, by means of a LICOR 3100 Leaf Area Integrator. Stalk diameter was determined in two plants, by measuring the section located below the ear insertion node with a caliper rule. Plant height (distance from the soil level to the insertion point of the highest leaf) and ear insertion height (distance from the soil level to the ear insertion node), and tassel characteristics were evaluated in the same ten plants selected at random from the usable area of each plot.

Experiment 2: Green ear yield, grain yield and other traits

This experiment was planted on the same date, in a neighboring area, and managed in a similar way. Differently from experiment 1 , each plot of this experiment consisted of four $6.0 \mathrm{~m}$ long rows of plants. The usable area was considered as the space occupied by the two central rows, with the elimination of plants from one pit at each end. One of the usable rows was chosen at random for green ear yield assessment, and the other was used for grain yield assessment. A total of 26 plants per usable row was grown, at a row spacing of $1.0 \mathrm{~m} \times 0.4 \mathrm{~m}$, with two plants per pit $\left(50,000\right.$ plants ha $\left.{ }^{-1}\right)$.

The evaluated traits were total number and mass of green ears; number and mass of marketable green ears, either unhusked or husked; fresh and dry mass of the above-ground part of the plant, tassels, and roots; leaf area, stalk diameter, plant height, and ear insertion height; grain yield and its components. The total number and mass of ears were estimated based on the total number of ears harvested from the usable area of the plot. The marketable unhusked ears considered were those free from damage caused by pests or diseases and with a length of $24 \mathrm{~cm}$ or longer, and marketable husked ears were those with good health and grain set, presenting a length of $18 \mathrm{~cm}$ or longer. The fresh and dry masses of the above-ground part of the plant, tassels, and roots; leaf area, and stalk diameter were evaluated after green ear harvesting. Plant height and ear insertion height were measured after dry ear harvesting. The number of dry ears was estimated based on the ears harvested from the usable area; the number of kernels per ear was obtained from 10 ears selected at random, and the 100-grain weight was estimated based on five samples of 100 kernels. Grain yield was corrected for a moisture content of $15.5 \%$ (wet basis).

\section{RESULTS AND DISCUSSION}

\section{Experiment 1: Baby corn yield and other traits}

The baby corn was harvested from 48 to 62 days after sowing, in seven harvest operations. Cultivars AG 405, AG 1051, and AG 2060 showed the most pronounced late behavior.

Cultivar DKB 333 B showed the greatest plant height and the greatest fresh mass of the above-ground part, 
Table 1. Means for plant height, ear insertion height, fresh matter of the above-ground part, number of tassel branchings, tassel fresh weight and tassel dry weight of corn cultivars evaluated for baby corn yield. Mossoró, ESAM, 2002/2003'

\begin{tabular}{|c|c|c|c|c|c|c|}
\hline Cultivars & Plant height $(\mathrm{cm})$ & Ear height $(\mathrm{cm})$ & $\begin{array}{l}\text { Fresh weight of } \\
\text { the above-ground } \\
\text { part (kg ha-1) }\end{array}$ & $\begin{array}{c}\text { Number of tassel } \\
\text { branchings }\end{array}$ & $\begin{array}{l}\text { Tassel fresh } \\
\text { weight }(\mathrm{mg})\end{array}$ & $\begin{array}{l}\text { Tassel dry weight } \\
\text { (mg) }\end{array}$ \\
\hline DKB 333B & $191 \mathrm{a}$ & $106 a b$ & $49,250 \mathrm{a}$ & $12 a b c$ & $430 a b$ & $210 a b c$ \\
\hline AG 405 & $186 a b$ & $109 a b$ & $45,036 \mathrm{ab}$ & $14 \mathrm{a}$ & $440 a b$ & $210 a b$ \\
\hline AG 1051 & $184 a b$ & $112 a$ & $40,536 a b$ & $11 a b c$ & $390 \mathrm{bc}$ & $190 \mathrm{bcd}$ \\
\hline AG 6690 & $176 \mathrm{ab}$ & $88 \mathrm{bc}$ & $43,000 \mathrm{ab}$ & $9 \mathrm{c}$ & $370 \mathrm{bcd}$ & $180 \mathrm{cde}$ \\
\hline AG 8080 & $176 a b$ & $82 \mathrm{c}$ & $39,928 \mathrm{ab}$ & $10 \mathrm{bc}$ & $310 \mathrm{~cd}$ & $160 \mathrm{de}$ \\
\hline DKB 747 & $160 \mathrm{ab}$ & $77 \mathrm{c}$ & $29,429 b$ & $13 a b$ & 490 a & $210 \mathrm{abc}$ \\
\hline AG 2060 & $174 a b$ & $88 \mathrm{bc}$ & $38,857 \mathrm{ab}$ & $12 \mathrm{abc}$ & 490 a & 240 a \\
\hline AG 7575 & $167 a b$ & $73 \mathrm{c}$ & $32,821 \mathrm{ab}$ & $8 \mathrm{c}$ & $290 \mathrm{~d}$ & $140 \mathrm{e}$ \\
\hline DKB 435 & $176 a b$ & $92 a b c$ & $33,893 \mathrm{ab}$ & $11 \mathrm{bc}$ & 380 bc & $180 \mathrm{bcd}$ \\
\hline DKB 350 & $153 \mathrm{~b}$ & $73 \mathrm{c}$ & $30,893 \mathrm{ab}$ & $11 \mathrm{bc}$ & $360 \mathrm{bcd}$ & $180 \mathrm{cde}$ \\
\hline C.V. $\%$ & 9 & 11 & 24 & 8 & 15 & 10 \\
\hline
\end{tabular}

${ }^{1}$ Means followed by a common letter do not differ among themselves by Tukey test $(\mathrm{P} \leq 0.05)$

Table 2. Means for the number and weight of marketable unhusked and husked baby corn ears of corn cultivars. Mossoró, ESAM, 2002/2003 ${ }^{1}$

\begin{tabular}{lccllc}
\hline \multirow{2}{*}{ Cultivars } & \multicolumn{2}{c}{ Unhusked ears } & & \multicolumn{2}{c}{ Husked ears } \\
\cline { 2 - 3 } \cline { 5 - 6 } & Number ha-1 & kg ha $^{-1}$ & & Number ha $\mathbf{~}^{-1}$ & kg ha $^{-1}$ \\
\hline DKB 333B & $91,505 \mathrm{bcd}$ & $3,627 \mathrm{bc}$ & & $46,718 \mathrm{bc}$ & $457 \mathrm{~b}$ \\
AG 405 & $80,695 \mathrm{~d}$ & $2,936 \mathrm{c}$ & & $24,324 \mathrm{c}$ & $186 \mathrm{~b}$ \\
AG 1051 & $87,066 \mathrm{~cd}$ & $3,384 \mathrm{bc}$ & & $30,309 \mathrm{c}$ & $323 \mathrm{~b}$ \\
AG 6690 & $133,691 \mathrm{abc}$ & $4,599 \mathrm{abc}$ & & $39,044 \mathrm{bc}$ & $371 \mathrm{~b}$ \\
AG 8080 & $107,529 \mathrm{bcd}$ & $5,672 \mathrm{a}$ & & $53,475 \mathrm{abc}$ & $526 \mathrm{ab}$ \\
DKB 747 & $140,723 \mathrm{ab}$ & $4,844 \mathrm{abc}$ & & $56,564 \mathrm{abc}$ & $482 \mathrm{~b}$ \\
AG 2060 & $76,448 \mathrm{~d}$ & $3,233 \mathrm{bc}$ & & $22,973 \mathrm{c}$ & $293 \mathrm{~b}$ \\
AG 7575 & $139,189 \mathrm{ab}$ & $4,719 \mathrm{abc}$ & & $43,243 \mathrm{bc}$ & $403 \mathrm{~b}$ \\
DKB 435 & $141,119 \mathrm{ab}$ & $5,008 \mathrm{ab}$ & & $68,146 \mathrm{ab}$ & $498 \mathrm{ab}$ \\
DKB 350 & $172,393 \mathrm{a}$ & $6,100 \mathrm{a}$ & & $83,765 \mathrm{a}$ & $877 \mathrm{a}$ \\
\hline C.V. \% & 21 & 22 & & 37 & 41 \\
\hline
\end{tabular}

Means followed by a common letter do not differ among themselves by Tukey test $(\mathrm{P} \leq 0.05)$

only differing from cultivar DKB 350, which had the shortest height, and from cultivar DKB 747, with respect to fresh mass of the above-ground part (Table 1). The greatest ear insertion height was shown by cultivar AG 1051, which exceeded all cultivars except of cultivars DKB 333 B, AG 405, and DKB 435 (Table 2). High plant densities may cause lodging in some cultivars, in certain environments (BAVEC; BAVEC, 2002), especially with increasing planting density it causes plant height and ear insertion height to increase as well (MODARRES et al., 1998). Since baby corn is generally produced under high planting densities, preference should be given to smallersized cultivars, in order to decrease yield losses, which might happen if lodging occurs before flowering.

Cultivars AG 7575 and AG 6690 showed the tassels with the smallest number of branchings and AG 7575 had the smallest fresh and dry masses (Table 1). The tassel functions as a strong sink organ, and may demand an expressive amount of photoassimilates (CHINWUBA et al., 1961). The competition effect for nutrients and carbohydrates between ear and tassel will be so much more severe as will the environment's adverse conditions (MAGALHÃES et al., 1993; GERALDI et al., 1985). In addition, large tassels cause leaf shading (HUNTER et al., 1969). On the other hand, there exist a negative correlation between tassel size and prolificacy (SOUZA JÚNIOR et al., 1985), which is a very important trait in cultivars intended for baby corn production. Thus, cultivars with smaller tassels seem to be important for both baby corn and grain production. It is interesting to point out that detasseling provides an increase in the productivity of commercial baby corn ears, regardless of sowing season (CARVALHO et al., 2002) or phosphorus rate applied (SAHOO; PANDA, 2001). However, the effect caused by tassel removal on forage yield varied with cropping season (SAHOO; PANDA, 2001).

There were no differences between cultivars with regard to leaf area, stalk diameter, dry mass of the above-ground part of the plant, and fresh and dry masses of the root system.

Cultivars DKB 350 and AG 8080 were the most productive with respect to the number and mass of marketable unhusked, and husked baby corn ears (Table 2). It becomes evident, therefore, that depending on the criterion used for yield assessment in baby corn (number or mass of unhusked or husked ears, and so on), cultivars can be different. Yields with a similar magnitude as those observed in the present work for mass of unhusked ears were observed by other authors (CARVALHO, 2002). In relation to husked ears, yields had a similar magnitude as those observed in other experiments (AEKATASNAWAN, 2001), but were lower than those verified in other researches (PEREIRA FILHO et al., 
1998; CARVALHO et al., 2002).

Cultivar AG 2060 showed ears with the largest mean diameter, to be sold either fresh or preserved (Table 3). With regard to ear length, the same cultivar and also cultivar AG 6690 yielded the largest ears to be sold fresh. In the case of ears to be sold as preserves, cultivar AG 7575 had high ear length. There were no differences between cultivars with regard to fresh and dry baby corn ear weight. The moisture content for baby corn ears varied from $88 \%$ (cultivar AG 405) to $91 \%$ (cultivar DKB 350). Other authors obtained a mean value of $89 \%$ (YODPET,1979) or a variation from $90 \%$ to $95 \%$ (CARVALHO, 2002).

Experiment 2: Green ear yield, grain yield, and other traits

The green ears were harvested from 68 to 76 days after planting date, in four harvesting operations. Cultivars AG 405, AG 1051, AG 8080, DKB 333B, and DKB 435 showed the most pronounced late behavior.

There were no differences between cultivars with regard to the total number and weight of green ears. Therefore, the cultivars differed only with respect to their number and weight of marketable ears, either unhusked or husked (Table 4). For these traits, cultivar DKB 747 and AG 8080 proved to be the most productive for number of unhusked marketable ears. Differences between cultivars with regard to traits for green

Table 3. Means for diameter and length of marketable baby corn ears, fresh and preserved, of corn cultivars. Mossoró, ESAM, 2002/2003

\begin{tabular}{lcccccc}
\hline \multirow{2}{*}{ Cultivars } & \multicolumn{3}{c}{ Ears to be sold fresh } & & \multicolumn{2}{c}{ Ears to be sold as preserves } \\
\cline { 2 - 3 } \cline { 6 - 7 } & Diameter $(\mathbf{c m})$ & Length $(\mathbf{c m})$ & & Diameter $(\mathbf{c m})$ & Length $(\mathbf{c m})$ \\
\hline DKB 333B & $1.31 \mathrm{bc}$ & $9.02 \mathrm{abcd}$ & & $1.24 \mathrm{bc}$ & $8.76 \mathrm{bc}$ \\
AG 405 & $1.37 \mathrm{abc}$ & $9.34 \mathrm{abc}$ & & $1.30 \mathrm{abc}$ & $8.88 \mathrm{ab}$ \\
AG 1051 & $1.39 \mathrm{abc}$ & $9.31 \mathrm{abc}$ & & $1.32 \mathrm{ab}$ & $8.96 \mathrm{ab}$ \\
AG 6690 & $1.38 \mathrm{abc}$ & $9.88 \mathrm{a}$ & & $1.28 \mathrm{abc}$ & $9.20 \mathrm{ab}$ \\
AG 8080 & $1.33 \mathrm{bc}$ & $8.26 \mathrm{~d}$ & & $1.26 \mathrm{bc}$ & $7.92 \mathrm{de}$ \\
DKB 747 & $1.31 \mathrm{bc}$ & $8.75 \mathrm{bcd}$ & & $1.24 \mathrm{bc}$ & $8.34 \mathrm{de}$ \\
AG 2060 & $1.50 \mathrm{a}$ & $9.90 \mathrm{a}$ & & $1.36 \mathrm{a}$ & $9.10 \mathrm{ab}$ \\
AG 7575 & $1.29 \mathrm{bc}$ & $9.70 \mathrm{ab}$ & & $1.26 \mathrm{bc}$ & $9.36 \mathrm{a}$ \\
DKB 435 & $1.26 \mathrm{c}$ & $8.42 \mathrm{~d}$ & & $1.22 \mathrm{c}$ & $8.06 \mathrm{~cd}$ \\
DKB 350 & $1.42 \mathrm{ab}$ & $8.42 \mathrm{~cd}$ & & $1.30 \mathrm{abc}$ & $7.76 \mathrm{e}$ \\
\hline C.V., \% & 5 & 3 & 3 & 6
\end{tabular}

Means followed by a common letter do not differ among themselves by Tukey test $(\mathrm{P} \leq 0.05$

corn yield evaluation were also observed by other authors (SILVA et al., 1997; SILVA et al., 1998).

There were no differences between cultivars with regard to leaf area, stalk diameter, fresh and dry masses of the above-ground part of the plant, tassel, and root system, evaluated after the final harvesting of green ears.

Among the evaluated traits after harvesting mature ears, there were differences between cultivars only with regard to plant height and ear insertion height, and with regard to weight of 100 grains (Table 4). Cultivars DKB 435 and DKB 747 showed the smallest means for both heights. The greatest mass of 100 grains was shown by cultivar AG 7575. The fact that cultivars differed with respect to green ear yield but showed the same grain yield could be due to several factors. Cultivars may differ with regard to their green ear cob and straw weights, but their grain at the "green corn stage" can still show different moisture contents (SILVA; PATERNIANI, 1986). Besides, at the time when green ears are harvested, grain filling is obviously not complete and cultivars may differ with regard to their grain filling rate and duration of the grain filling period (PONELEIT; EGLI, 1979). Finally, ears considered unsuitable for green corn production can be perfectly used for grain production.

Cultivar DKB 350 and AG 8080 were the most productive with respect to the number and weight of marketable

Table 4. Means for the number and mass of marketable, unhusked and husked green ears, plant height, and ear insertion height, and 100dry-grain weight of corn cultivars. Mossoró, ESAM, 2002/2003 ${ }^{1}$

\begin{tabular}{|c|c|c|c|c|c|c|c|}
\hline \multirow{3}{*}{ Cultivars } & \multicolumn{4}{|c|}{ Marketable green ears } & \multicolumn{2}{|c|}{ Heights } & \multirow{3}{*}{$\begin{array}{c}100 \text {-grain } \\
\text { weight }(\mathrm{g})\end{array}$} \\
\hline & \multicolumn{2}{|c|}{ Unhusked } & \multicolumn{2}{|c|}{ Husked } & Plant & Ear & \\
\hline & No. ha-1 & kg ha-1 & No. ha-1 & kg ha-1 & & & \\
\hline DKB 333B & 26,682 bc & $6,932 \mathrm{c}$ & $17,430 \mathrm{ab}$ & $2,951 \mathrm{~b}$ & 202 a & 108 a & $36 a b c$ \\
\hline AG 8080 & 39,066 a & $10,958 a b$ & $17,902 a b$ & $3,508 \mathrm{~b}$ & $195 a b$ & $90 \mathrm{ab}$ & $33 \mathrm{bc}$ \\
\hline AG 6690 & $37,675 \mathrm{ab}$ & $10,659 a b c$ & $27,227 \mathrm{ab}$ & $4,998 a b$ & $188 a b$ & $96 a b$ & $35 \mathrm{abc}$ \\
\hline AG 405 & $35,817 \mathrm{ab}$ & $9,874 \mathrm{abc}$ & $20,876 a b$ & $4,098 a b$ & $188 a b$ & $84 a b$ & $40 a b$ \\
\hline DKB 350 & $33,878 \mathrm{abc}$ & $8,945 \mathrm{abc}$ & $27,596 a b$ & $5,232 a b$ & $186 a b$ & $89 a b$ & $35 a b c$ \\
\hline AG 1051 & $24,113 \mathrm{c}$ & $6,998 \mathrm{c}$ & $15,496 \mathrm{~b}$ & $3,105 b$ & $184 a b$ & $90 \mathrm{ab}$ & $38 \mathrm{abc}$ \\
\hline AG 2060 & $32,052 \mathrm{abc}$ & $9,317 \mathrm{abc}$ & $23,613 a b$ & $4,957 a b$ & $183 a b$ & $88 a b$ & $37 \mathrm{abc}$ \\
\hline AG 7575 & $32,104 \mathrm{abc}$ & $7,680 \mathrm{bc}$ & $23,415 a b$ & $3,629 \mathrm{~b}$ & $182 a b$ & $94 a b$ & $41 \mathrm{a}$ \\
\hline DKB 435 & $36,026 a b$ & $8,709 a b c$ & $25,000 a b$ & $3,798 a b$ & $164 b$ & $78 \mathrm{~b}$ & $32 \mathrm{c}$ \\
\hline DKB 747 & 39,961 a & $11,630 \mathrm{a}$ & $32,194 \mathrm{a}$ & $6,430 \mathrm{a}$ & $164 \mathrm{~b}$ & $74 \mathrm{~b}$ & $36 \mathrm{abc}$ \\
\hline C.V., \% & 16 & 18 & 30 & 29 & 9 & 15 & 10 \\
\hline
\end{tabular}

Means followed by a common letter do not differ among themselves by Tukey test $(\mathrm{P} \leq 0.05)$. 
unhusked, and husked baby corn ears. Cultivar DKB 747 and AG 8080 were the most productive with respect to the number and weight of marketable, unhusked, and husked ears. There were no differences between cultivars with respect to grain yield. Therefore, the best cultivars can be different when different corn exploiting purposes are taken into account.

\section{LITERATURE CITED}

AEKATASANAWAN, C. Baby corn. In: HALLAUER, A.R. Specialty Corns. 2 ed. Madison, CRC Press LLC, 2001, v.2, cap.9, p.275-293.

BAVEC, F.; BAVEC, M. Effects of plant population on leaf area index, cob characteristics and grain yield of early maturing maize cultivars. European Journal of Agronomy, v.6, n.2, p.151-159, 2002.

CARVALHO, G.S. Caracterização agronômica e nutricional de milho sob diferentes condições de cultivo para produção de minimilho. $2002.70 \mathrm{f}$ (Dissertação de Mestrado em Fitotecnia) - Universidade Federal de Lavras, Lavras.

CARVALHO, G.S.; VON PINHO, R.G.; PEREIRA FILHO, I.A. Efeito do tipo de cultivar, despendoamento das plantas e da época de semeadura na produção de minimilho. Revista Brasileira de Milho e Sorgo. Sete Lagoas, v.1, n.3, p.4758, 2002.

CHINWUBA, P.M.; GROGAN, C.O.; ZUBER, M.S. Interaction of detasseling, sterility and spacing of maize hybrids. Crop Science, v.1, n.2, p.279-280, 1961
GERALDI, I.O.; MIRANDA FILHO, J.B.; VENCOVSKY, R. Estimatives of genetic parameters for tassel characters in maize ( $\mathrm{Zea}$ mays L.) and breeding perspectives. Maydica, v.30, n.1, p.1-14, 1985.

HUNTER, R.B.; DAYNARD, T.B.; HUME, D.J.; TANNER, J.W.; CURTIS, J.D.; KANNENBERG, L.W. Effect of tassel removal on grain yield of corn (Zea mays L.). Crop Science, v.9, n.4, p.405406, 1969.

MAGALHÃES, P.C.; GAMA, E.E.G.; MAGNAVACA, R. Efeito de diferentes tipos de despendoamento no comportamento e produção de alguns genótipos de milho. Sete Lagoas: EMBRAPA/CNPMS, 1993. 4 p. (Pesquisa em andamento, 12).

MODARRES, A.M.; DIJACK, M.; HAMILTON, R.I; DWYER, L.M.; STEWART, D.M.; MATHER, D.E.; SMITH, D.L. Leafy reducedstature maize hybrid response to plant population density and planting patterns in a short growing season area. Maydica, v.43, n.1, p.227-234, 1998. PANDEY, A.K.; MANI, V.P., PRAKASH, V.; SINGH, R.D.; GUPTA, H.S. Effect of varieties and plant densities on yield, yield attributes and economics of babycorn (Zea mays). Indian Journal of Agronomy, v.47, n.2, p.221-226, 2002. PEREIRA FILHO, I.A.; GAMA, E.E.G.; CRUZ, J.C. Minimilho: efeito de densidade de plantio e cultivares na produção e em algumas características da planta do milho. In: EMBRAPA. Centro Nacional de Pesquisa de Milho e Sorgo. Sete Lagoas, 1998. 6 p. (EMBRAPA - CNPMS. Pesquisa em andamento, 23).

PONELEIT, C.G.; EGLI, D.B. Kernel growth rate and duration in maize as affected by plant density and genotype. Crop Science, v.19, n.3, p.385-388, 1979.
SAHOO, S.C.; PANDA, M.M. Effect of phosphorus and detasseling on yield of baby corn (Zea mays L.). Indian Journal of Agricultural Sciences, v.71, n.1, p.21-22, 2001

SILVA, P.S.L.; PATERNIANI, E. Produtividade de milho verde e grãos de cultivares de Zea mays L. Ciência e Cultura, São Paulo, v.38, n.4, p.707712, 1986.

SILVA, K.M.B.; SILVA, P.S.L. Produtividade de grãos verdes e secos de milho e de caupi. Horticultura Brasileira, Brasília, v.9, n.2, p.8789, 1991.

SILVA, P.S.L.; BARRETO, H.E.P.; SANTOS, M.X. Avaliação de cultivares de milho quanto aos rendimentos de grãos verdes e secos. Pesquisa Agropecuária Brasileira, Brasília, v.32, n.1, p.6369, 1997.

SILVA, P.S.L.; SILVA, K.M.B.; SILVA, N.L.; DINIZ FILHO, E.T.; SANTOS, M.X. Rendimentos de grãos verdes e secos de cultivares de milho I. Período 1985-90. Revista Ceres, Viçosa, v.45, n.257, p.89-115, 1998.

SOUZA JÚNIOR, C.L. GERALDI, I.O.; ZINSLY;

J.R. Influence of tassel size on the expression of prolificacy in maize (Zea mays L.). Maydica, v.30, n.3, p.321-328, 1985.

YODPET, C. Studies on sweet corn as potencial young cob corn (Zea mays L.). Laguna, University of the Philippines, Los Banos College, 1979. Ph.D. Thesis. $68 \mathrm{p}$. 